\title{
Analisis Efisiensi pada Pra dan Pasca Initial Public Offering (IPO) Panin Dubai Syariah Bank
}

\section{Analysis of Efficiency in Pre and Post Initial Public Offering (IPO) Panin Dubai Syariah Bank}

\author{
Dina Wening Ati Dianti ${ }^{1}$, Irfan Syauqi Beik ${ }^{2}$, dan Ascarya ${ }^{3}$ \\ ${ }^{1}$ Institut Pertanian Bogor, Jalan Raya Dramaga, Bogor 16680, dina.wening.ati@gmail.com \\ ${ }^{2}$ Institut Pertanian Bogor, Jalan Raya Dramaga, Bogor 16680, qibeiktop@gmail.com \\ ${ }^{3}$ Institut Pertanian Bogor, Jalan Raya Dramaga, Bogor 16680, as carya@yahoo.com
}

\begin{abstract}
Panin Dubai Syariah Bank (PDSB) conducted an initial public offering (IPO) in January 2014 and was also registered as the first Islamic bank (IB) to conduct an IPO. With an IPO, PDSB is required to provide information disclosure and increase the company's competitive advantage. This study aims to determine 1) financial performance pre and post implementation of the PDSB IPO;2) the efficiency of the pre and post implementation of the PDSB IPO compared to the IB BUKU 2. The study used a quantitative descriptive approach. The type of data used is secondary data in the form of annual report IB BUKU 2 2010-2017 and IB publication reports. Data were analyzed using the Data Envelopment Analysis (DEA) model to measure efficiency as a concept for evaluating PDSB performance. The results showed (1) CAR pre IPO better than post IPO. BOPO, NPF and FDR there are no significant differences between pre IPO and post IPO (2) PDSB efficiency scores in 2010-2017 are always more efficient when compared to IB BUKU 2. There are significant differences in the parameters of technical efficiency, pure technical efficiency, and scale efficiency on pre-IPO, while post-IPO significant differences only in the efficiency of technical efficiency and scale efficiency.
\end{abstract}

Keywords: Data Envelopmet Analysis (DEA), efficiency, Initial Public Offering (IPO), Panin Dubai Syariah Bank

\begin{abstract}
Abstrak. Panin Dubai Syariah Bank (PDSB) melaksanakan initial public offering (IPO) pada Januari 2014 dan juga terdaftar sebagai bank syariah pertama yang melakukan IPO. Dengan IPO, PDSB dituntut untuk memberikan keterbukaan informasi dan meningkatkan competitive advantage perusahaan. Penelitian ini bertujuan untuk mengetahui 1) kinerja keuangan pra dan pasca pelaksanaan IPO PDSB; 2) efisiensi pra dan pasca pelaksanaan IPO PDSB dibandingkan BUS BUKU 2. Penelitian menggunakan pendekatan deskriptif kuantitatif. Jenis data yang digunakan adalah data sekunder berupa annual report BUS BUKU 2 tahun 2010-2017 dan laporan publikasi BUS. Data dianalisis menggunakan model Data Envelopment Analysis (DEA) untuk mengukur efisiensi sebagai konsep untuk mengevaluasi kinerja PDSB. Hasil penelitian menunjukkan (1) CAR pra IPO lebih lebih baik dibandingkan pasca IPO. BOPO, NPF dan FDR tidak ada perbedaan siginifikan antara pra IPO dan pasca IPO (2) skor efisiensi PDSB tahun 2010-2017 selalu lebih efisien bila dibandingkan BUS BUKU 2. Terdapat perbedaan signifikan pada parameter efisiensi teknis, efisiensi teknis murni, dan efisiensi skala pada pra IPO, sedangkan pasca IPO perbedaan signifikan hanya pada efisiensi teknis dan efisiensi skala.
\end{abstract}

Kata kunci: Data Envelopmet Analysis (DEA), efisiensi, Panin Dubai Syariah Bank, penawaran saham perdana (IPO)

\section{PENDAHULUAN}

\section{Latar Belakang}

Berdasarkan data Statistik Perbankan Syariah Otoritas Jasa Keuangan, pada akhir tahun 2017 terdapat 13 Bank Umum Syariah (BUS). Dari ke 13 BUS hanya satu yang masuk ke dalam kategori Bank Umum Kegiatan Usaha (BUKU) 3 atau memiliki modal inti lebih dari Rp 5 triliun. Sembilan BUS masuk dalam kategori BUKU 2 dengan modal inti minimal Rp 1 triliun. Tiga BUS lainnya masuk dalam kategori BUKU 1 dengan modal inti minimal Rp 100 miliar. Total aset BUS BUKU 2 mendominasi sebesar $63.54 \%$ dari aset perbankan syariah Indonesia di tahun 2017 , sehingga kondisi 
yang dihadapi BUS BUKU 2 cukup menggambarkan kondisi perbankan syariah di Indonesia. Salah satunya adalah kondisi permodalan yang menjadi isu strategis yang dihadapi hampir semua BUS yang mengakibatkan keterbatasan pengembangan infrastruktur dan segmen layanan yang lebih bervariasi.

Initial Public Offering (IPO) atau penawaran saham kepada masyarakat merupakan salah satu upaya yang dapat ditempuh untuk mengatasi kendala permodalan. Menurut Hendy (2008), dana yang diperoleh dari go public umumnya digunakan untuk berbagai kebutuhan perusahaan seperti kebutuhan ekspansi, menambah modal kerja, membayar utang, peningkatan investasi di anak perusahaan, memperbaiki struktur permodalan, dan lain-lain. Salah satu BUS BUKU 2 yaitu PDSB pada Januari 2014 mencatatkan sahamnya di bursa. PDSB telah berhasil menghabiskan dana sebesar Rp 467.64 miliar dengan rincian penggunaan antara lain sebesar Rp 374.11 miliar untuk pembiayaan modal kerja dan Rp 93.53 miliar untuk pengembangan jaringan dan infrastruktur.

Abraham et al. (2016) menyebutkan bahwa IPO mengkomunikasikan sinyal positif yang kuat bahwa perusahaan akan memulai periode pertumbuhan dengan berhasil menggunakan modal baru yang diajukan. Hal ini didukung oleh penelitian Yin, Yang \& Mehran (2015) yang menunjukkan bank yang memilih untuk go public secara signifikan lebih efisien daripada yang tidak. Lebih lanjut penelitian ini menunjukkan bahwa kinerja bank secara signifikan mengungguli rekan-rekan mereka sebelum IPO, namun keunggulan kinerja ini segera menghilang setelah IPO. Berdasarkan hasil penelitian tersebut, maka menjadi menarik untuk mengetahui lebih lanjut kinerja keuangan serta efisiensi PDSB bila dibandingkan peer group BUS BUKU 2, ditinjau pada kondisi pra dan pasca IPO PDSB.

\section{TINJAUAN PUSTAKA}

Efisiensi menurut Wheelock \& Wilson (1999) adalah ukuran penting dari kondisi operasional bank dan merupakan indikator kesuksesan suatu bank. Efisiensi dapat ditinjau dari berbagai sisi. Salah satu indikator yang umum menggambarkan efisiensi perbankan adalah rasio BOPO. BOPO merupakan perbandingan antara biaya operasional terhadap pendapatan operasional. Pada umumnya semakin kecil BOPO maka perbankan berada dalam kondisi semakin efisien. Pada penelitian ini efisiensi yang dimaksud menggunakan pendekatan frontier DEA nonparametrik.

Sharma, Sharma \& Barua (2013) meninjau 106 penelitian yang mengukur efisiensi dan produktivitas industri perbankan pada periode tahun 1994 hingga 2011. Penelitian tersebut menunjukkan bahwa sebanyak $75 \%$ penelitian menggunakan metode nonparametrik DEA untuk mengukur efisiensi. DEA adalah suatu teknik pemrograman matematika yang mengukur tingkat efisiensi dari Unit Pengambil Keputusan (UPK) relatif terhadap UPK yang sejenis ketika semua unit-unit ini berada pada atau di bawah kurva frontier efisiensinya. Masing-masing UPK terdiri dari input dan output. Selanjutnya, kinerja dari suatu UPK sangat relatif terhadap UPK lainnya, khususnya yang menyebabkan inefisiensi. Pendekatan ini juga dapat melihat bagaimana suatu UPK itu melakukan penyempurnaan kinerja keuangannya sendiri sehingga menjadi efisien (Charnes, Cooper \& Rhodes, 1978).

Penelitian mengenai efisiensi diantaranya Ascarya \& Yumanita (2006) yang berjudul "Analisis efisiensi perbankan syariah di Indonesia dengan Data Envelopment Analysis". Penelitian ini mengukur efisiensi menggunakan DEA dengan pendekatan produksi dan intermediasi, serta mengidentifikasi penyebab inefisiensi. Objek penelitian adalah seluruh BUS, UUS dan BPRS periode 2000-2004. Dari penelitian tersebut dapat disimpulkan bahwa secara umum bank syariah mengalami penurunan efisiensi teknis, namun efisiensi skala mengalami peningkatan karena BUS cukup agresif dalam ekspansi pembukaan jaringan kantor.

Yahya, Muhammad \& Hadi (2012) dalam penelitian berjudul "A Comparative study on the level of efficiency between Islamic and conventional banking systems in Malaysia" membandingkan tingkat efisiensi perbankan syariah dan konvensional di Malaysia menggunakan DEA dengan pendekatan intermediasi. Pendekatan intermediasi dilakukan dengan pertimbangan keterbatasan jumlah data yang digunakan. Hasil penelitian menunjukkan bahwa tidak ada perbedaan yang signifikan dalam tingkat 
efisiensi antara bank syariah dan bank konvensional. Meskipun bank syariah dalam kegiatan operasionalnya dibatasi oleh syariat Islam, namun mampu mempertahankan kinerja yang setara dengan bank konvensional.

Qureshi \& Shaikh (2012) dalam penelitian berjudul "Efficiency of Islamic and conventional banks in Pakistan: A Non-parametric approach" menganalisis kinerja efisiensi bank syariah dan bank konvensional di Pakistan menggunakan DEA melalui pendekatan intermediasi. Studi ini menunjukkan bahwa bank syariah memiliki kinerja yang lebih efisien dibandingkan dengan bank konvensional di Pakistan.

Majeed \& Zanib (2016) dalam penelitian berjudul "Efficiency analysis of Islamic banks in Pakistan" membandingkan tingkat efisiensi teknis, alokatif dan skala pada tiga jenis bank yaitu full pledged Islamic bank, cabang syariah dari bank konvensional dan bank konvensional di Pakistan. Data diolah dengan metode DEA, pendekatan intermediasi dengan waktu penelitian dari tahun 2007 hingga 2014. Total 15 sampel yang masing-masing jenis bank diwakili oleh 5 sampel. Variabel input yaitu simpanan nasabah, aset tetap dan modal. Variabel output terdiri dari investment, pembiayaan dan aset lain yang terkait, dan total aset. Hasil penelitian menunjukkan bahwa bank konvensional adalah yang paling efisien dalam hal efisiensi teknis total dan efisiensi teknis murni dibandingkan full pledged Islamic bank. Sementara itu cabang syariah dari bank konvensional lebih baik dalam efisiensi skala.

Penelitian efisiensi pada sektor perbankan yang melakukan IPO masih sangat terbatas. Penelitian pernah dilakukan oleh Yin, Yang \& Mehran (2015) yang berjudul "Do Chinese banks perform better after IPOs?" menyelidiki efek dari IPO pada kinerja bank di Cina. Penelitian dengan menggunakan metode parametrik SFA untuk mengukur efisiensi bank dan seleksi serta efek dinamis dari pencatatan perusahaan dalam bursa saham. Hasil penelitian menunjukkan bahwa terdapat efek seleksi yang kuat. Artinya, bank yang memilih untuk go public secara signifikan lebih efisien daripada yang tidak. Namun, analisis efek dinamis tidak menunjukkan bukti bahwa efisiensi bank meningkat setelah go public, baik dalam jangka pendek atau dalam jangka panjang.

Dengan analisis nonparametrik, penulis menganalisis lebih lanjut kinerja bank dalam periode menjelang IPO dan menemukan bahwa bank secara signifikan mengungguli rekan-rekan mereka sebelum IPO. Namun keunggulan kinerja ini segera menghilang setelah IPO sehingga konsisten dengan hipotesis perusahaan mengambil langkah oportunis saat penyusunan laporan kinerja menjelang IPO.

Penelitian efisiensi pada sektor perbankan yang melakukan IPO dengan metode DEA belum pernah dilakukan. Penelitian yang membandingkan efisiensi pra dan pasca IPO di sektor perbankan menggunakan metode DEA juga belum pernah dilakukan. Sehingga penulis memandang perlu dilakukan penelitian yang membandingkan kinerja keuangan serta efisiensi pra dan pasca IPO sektor perbankan dengan PDSB sebagai objek penelitian.

\section{METODE}

Pengumpulan dan pengolahan data sekunder dilakukan selama enam bulan dari bulan Januari-Juni 2019. Penelitian ini menggunakan pendekatan deskriptif kuantitatif. Penelitian diawali dengan pengumpulan laporan keuangan BUS BUKU 2 dan agregat BUS kemudian pemilihan input dan output dengan pendekatan intermediasi guna mendapatkan nilai efisiensi. Perhitungan efisiensi yang dihitung dengan pendekatan Data Envelopment Analysis menggunakan software Banxia Frontier Analysis 4. Ascarya \& Yumanita (2006) menyebutkan keuntungan dari penggunaan DEA adalah bahwa pendekatan ini tidak memerlukan spesifikasi yang eksplisit dari bentuk fungsi dan hanya memerlukan sedikit struktur untuk membentuk frontier efisiensinya. Kelemahan yang mungkin muncul adalah self identifier dan near self identifier. 
Spesifikasi input dan output menggunakan pendekatan intermediasi. Berger \& Humphrey (1997) mengemukakan bahwa pendekatan intermediasi adalah yang terbaik untuk mengevaluasi seluruh bank karena melibatkan biaya bunga (pendapatan dibayarkan kepada deposan) yang sering menyumbang satu setengah hingga dua pertiga dari total biaya. Pendekatan intermediasi adalah teknik yang paling banyak digunakan untuk mengukur efisiensi (Kwan, 2003). Input dan output dengan pendekatan intermediasi terdiri atas aset tetap (x1), biaya tenaga kerja (x2), Dana Pihak Ketiga (x3). Sedangkan output terdiri atas investment (y1), pembiayaan murabahah (y2) dan pembiayaan bagi hasil (y3).

\section{Model DEA Constant Return to Scale (CRS)}

Kumpulan input dan output dibutuhkan untuk menilai tingkatan efisiensi dari sebuah perusahaan atau membandingkan beberapa perusahaan dalam sebuah industri. Apabila semua perusahaan dalam industri memproduksi tingkat output yang optimal secara konstan, maka dapat dikatakan hal tersebut merupakan bentuk dari skala hasil yang tetap (constant return to scale) atau CRS.

Charnes, Cooper \& Rhodes (1978) mengembangkan model DEA yang berdasarkan konsep CRS, di mana model ini mengasumsikan bahwa semua UPK bekerja pada skala yang optimal pada operasionalnya. Model ini seringkali dikenal dengan model CCR dalam pengukuran efisiensi dengan DEA. Model ini mengasumsikan bahwa rasio antara penambahan input dan output adalah sama (constant return to scale). Artinya, jika ada tambahan input sebesar x kali, maka output akan meningkat sebesar x kali juga. Asumsi lain yang digunakan dalam model ini adalah bahwa setiap perusahaan atau UPK beroperasi pada skala yang optimal. Rumus dari CRS dalam DEA dapat dituliskan sebagai berikut:

$$
\max _{\mu_{k} v_{t}} \sum_{k=1}^{p} \mu_{k} y_{k 0}
$$

Subject to

$$
\begin{aligned}
& \sum_{i=1}^{m} v_{i} x_{i 0}=1 \\
& \sum_{k=1}^{p} \mu_{k} y_{k j}-\sum_{i=1}^{m} v_{i}-x_{i j} \leq 0 \\
& \mu_{k} \geq \varepsilon, v_{i} \geq \varepsilon \\
& \mathrm{j}=1, \ldots, \mathrm{n} \\
& \mathrm{k}=1, \ldots, \mathrm{p} \\
& \mathrm{i}=1, \ldots, \mathrm{m}
\end{aligned}
$$

Di mana maksimal (max) di atas merupakan efisiensi teknis (CCR), xij adalah banyaknya input tipe ke-i dari UPK ke-j dan ykj adalah jumlah output tipe ke-k dari UPK ke-j. Nilai efisiensi selalu kurang atau sama dengan 1. UPK yang nilai efisiensinya kurang dari 1 berarti inefisien, sedangkan UPK yang nilai efisiensinya sama dengan 1 berarti UPK tersebut efisien.

\section{Model DEA Variable Return to Scale (VRS)}

Konsep variable return to scale (VRS) dalam metode DEA pertama kali dikembangkan oleh Banker, Charnes \& Cooper sebagai pengembangan dari metode DEA yang diperkenalkan oleh Farrel (1957). Dalam penelitian yang dilakukan oleh Banker, Charnes \& Cooper (1984), terdapat pembaharuan dari model CCR sebelumnya, yaitu adanya variabel baru yang terpisah yang memungkinkan untuk mengetahui apakah operasi yang dijalankan dalam suatu wilayah meningkat, tetap, atau menurun berdasarkan skalanya (pada situasi multiple input dan output). Sehingga dapat diketahui apakah skala usahanya sedang meningkat atau menurun. Dan model BCC ini dapat diaplikasikan pada skala ekonomi yang berbeda dari sebuah industri.

Banker, Charnes \& Cooper (1984) menyarankan perubahan dari CRS DEA menjadi variabel VRS DEA. Model ini beranggapan bahwa perusahaan tidak atau belum beroperasi pada skala yang optimal. Asumsi dari model ini adalah bahwa rasio antara penambahan input dan output tidak sama (variable return to scale). Artinya, penambahan input sebesar x kali tidak akan menyebabkan output meningkat 
sebesar x kali, bisa lebih kecil atau lebih besar dari x kali. Rumus VRS dapat dituliskan dalam fungsi matematis sebagai berikut:

$$
\max _{\mu_{k} v_{t}} \sum_{k=1}^{p} \mu_{k} y_{k 0}-\mu_{0}
$$

$$
\begin{aligned}
& \sum_{i=1}^{\text {Subject to }} v_{i} x_{i 0}=1 \\
& \sum_{k=1}^{m} \mu_{k} y_{k j}-\sum_{i=1}^{m} v_{i j}-\mu_{0} \leq 0 \\
& \mu_{k} \geq \varepsilon, v_{i} \geq \varepsilon \\
& j=1, \ldots, n \\
& k=1, \ldots, p \\
& i=1, \ldots, m
\end{aligned}
$$

Maksimalisasi di atas merupakan nilai efisiensi teknis (BCC), xij adalah banyaknya input tipe ke-i dari UPK ke-j, dan ykj adalah jumlah output tipe ke-k dari UPK ke-j. Nilai dari efisiensi tersebut selalu kurang atau sama dengan 1. UPK yang nilai efisiensinya kurang dari 1 berarti inefisiensi sedangkan UPK yang nilainya sama dengan 1 berarti UPK tersebut efisien.

Selanjutnya dilakukan analisis efisiensi pra dan pasca IPO PDSB yang hasilnya akan dilakukan uji beda dengan hasil efisiensi BUS dan BUS BUKU 2.Uji hipotesis $t$-Test adalah uji hipotesis yang digunakan untuk mengetahui apakah ada perbedaan rata-rata dari sampel yang diambil.

\section{HASIL DAN PEMBAHASAN}

\section{Kinerja Keuangan BUS BUKU 2}

BUS BUKU 2 terdiri atas sembilan BUS yaitu Bank Muamalat, Bank Mega Syariah, BRI Syariah, BCA Syariah, BNI Syariah, BTPN Syariah, Panin Dubai Syariah Bank, Maybank Syariah dan Bank Aceh Syariah. Tahun 2017 BUS BUKU 2 memberi kontribusi sebesar $63.54 \%$ dari total aset BUS secara nasional.

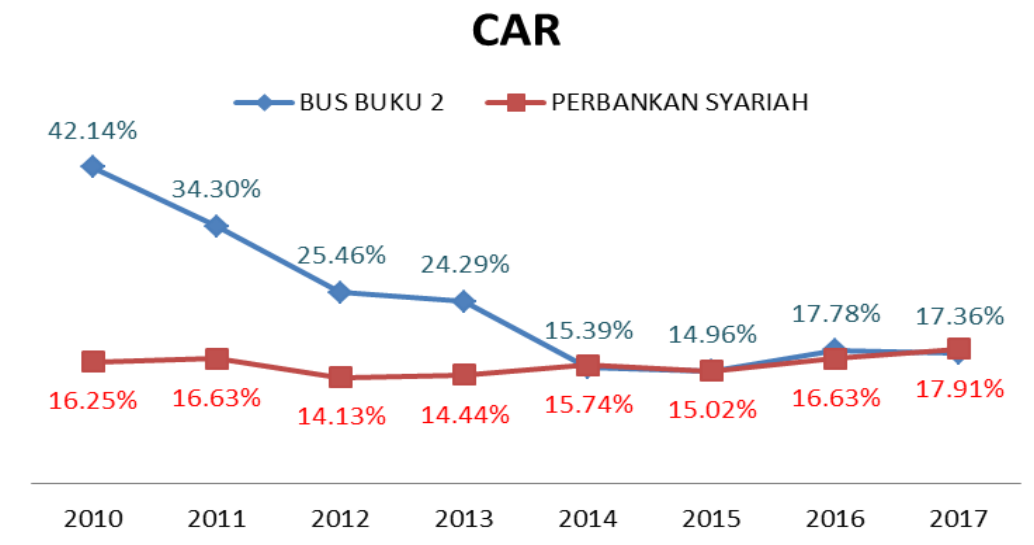

Sumber: Annual Report BUS BUKU 2, 2010-2017 dan SPS, 2012-2017

Gambar 1 CAR tahun 2010-2017

CAR BUS BUKU 2 selalu di atas CAR perbankan syariah dan di atas $8 \%$ ambang batas minimum CAR. CAR BUS BUKU 2 dan perbankan syariah memiliki arah pergerakan yang hampir sama kecuali pada masa krisis. Peningkatan atau penurunan CAR pada BUS BUKU 2 lebih tajam 
dibandingkan perbankan syariah. Fluktuasi nilai CAR yang tinggi menggambarkan fluktuasi pergerakan modal dibandingkan pertumbuhan ATMR.

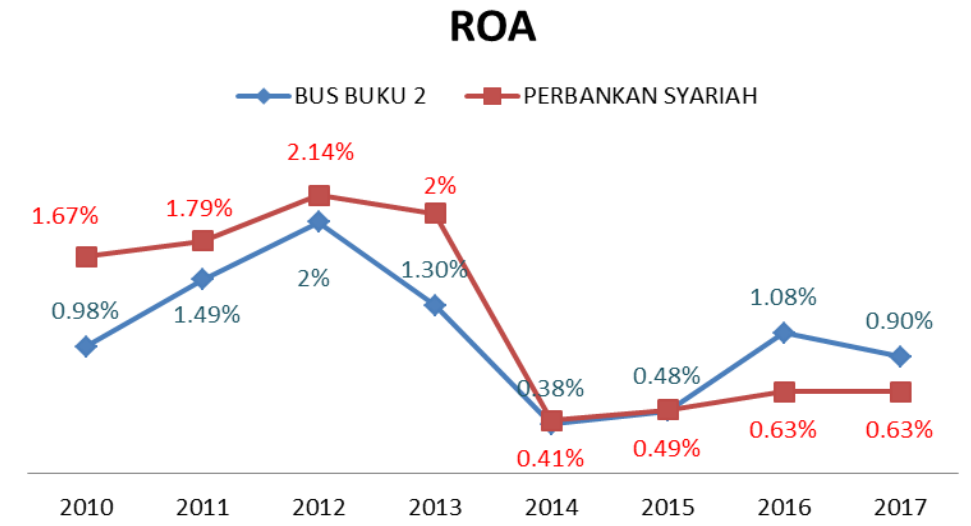

Sumber: Annual Report BUS BUKU 2, 2010-2017 dan SPS, 2012-2017

Gambar 2 ROA tahun 2010-2017

Tahun 2014 ROA perbankan syariah menurun tajam sebesar 1.6 poin menjadi $0.41 \%$ dan menjadi yang terendah dalam 10 tahun terakhir. Perbaikan kondisi ekonomi tahun 2015 sedikit meningkatkan ROA perbankan syariah dan BUS BUKU 2. ROA perbankan syariah berturut-turut $0.49 \%$ (tahun 2015), $1.08 \%$ (tahun 2016) dan menurun menjadi $0.90 \%$ pada tahun 2017. Sedangkan ROA BUS BUKU 2 0.49\% pada tahun 2015 dan terjaga di 0.63\% pada tahun 2016 hingga 2017.

\section{BOPO}

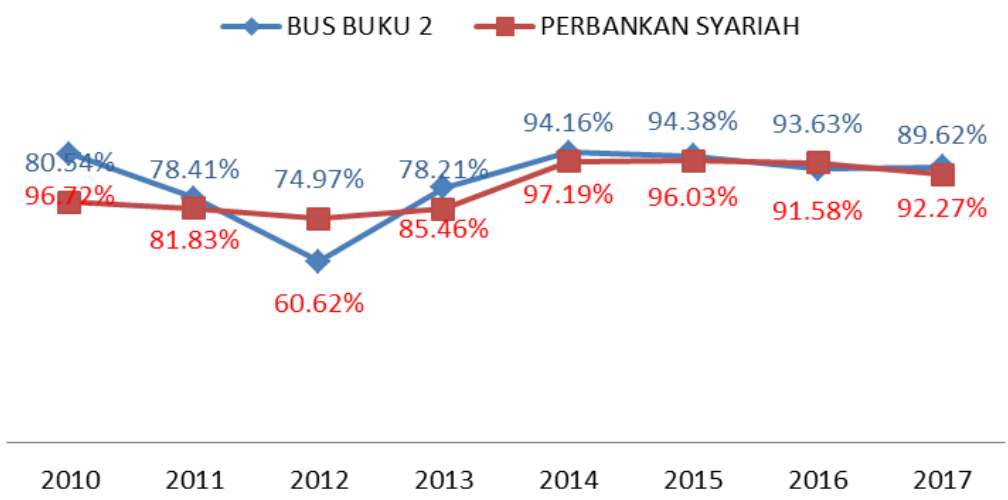

Sumber: Annual Report BUS BUKU 2, 2010-2017 dan SPS, 2012-2017

Gambar 3 BOPO tahun 2010-2017

Sejak tahun 2012 tren BOPO perbankan syariah menjadi lebih tinggi dibandingkan perbankan konvensional. Sejak tahun 2014, BOPO perbankan syariah termasuk BUS BUKU 2 semakin tinggi menyentuh angka lebih dari 90\%. Dengan tolak ukur perhitungan BOPO, maka kondisi ini menunjukkan perbankan syariah dan BUS BUKU 2 semakin tidak efisien.

FDR BUS BUKU 2 secara konsisten lebih tinggi dari perbankan syariah. Pada tahun 2013-2017, kondisi perekonomian tumbuh tidak sepesat tahun sebelumnya sehingga FDR baik perbankan syariah maupun BUS BUKU 2 sama-sama mengalami tren menurun selama empat tahun berturut-turut. Pengetatan realisasi pembiayaan sebagai bentuk konsolidasi perbankan dalam rangka memperbaiki 
kinerja merupakan salah satu faktor yang menyebabkan penurunan FDR di perbankan syariah maupun BUS BUKU 2.

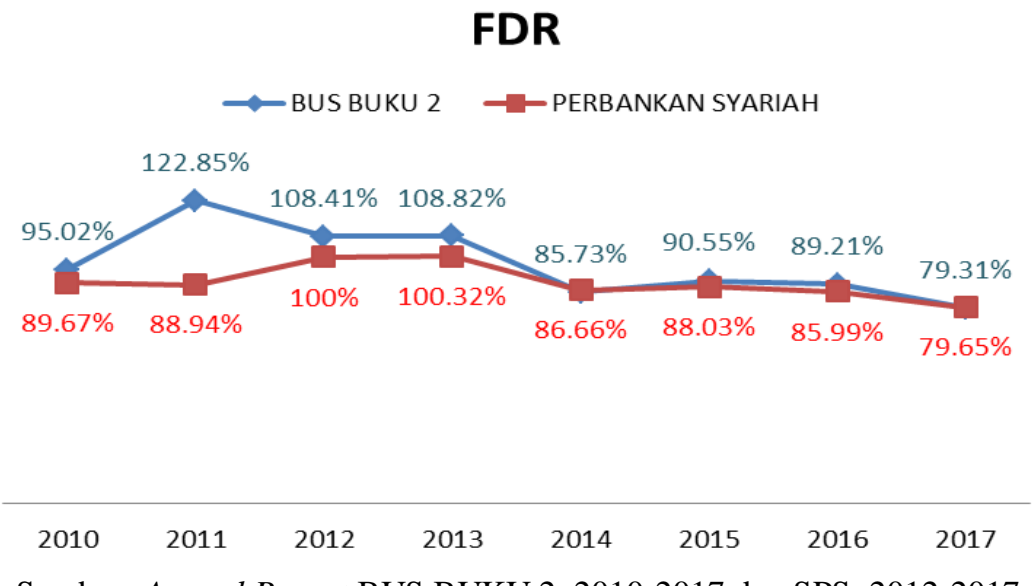

Sumber: Annual Report BUS BUKU 2, 2010-2017 dan SPS, 2012-2017

Gambar 4 FDR tahun 2010-2017

\section{Skor Efisiensi BUS BUKU 2}

Efisiensi bank merupakan salah satu indikator penting untuk menganalisis performance suatu bank dan juga sebagai sarana untuk lebih meningkatkan efektifitas kebijakan moneter (Mansyur, 2012). Skor efisiensi 100 menunjukkan bahwa perusahaan semakin efisien dalam kegiatan operasionalnya, semakin mampu untuk menghasilkan sejumlah output tertentu dengan kombinasi input minimum, serta semakin optimal menjalankan fungsinya sebagai lembaga intermediasi. Fluktuasi rata-rata skor efisiensi BUS BUKU 2 memiliki kecenderungan sama dengan fluktuasi efisiensi BUS. Pure technical efficiency atau efisiensi teknis murni (PTE) BUS BUKU 2 menggunakan model VRS adalah sebagai berikut:

Tabel 1 Skor efisiensi teknis murni (PTE) BUS BUKU 2

\begin{tabular}{ccccccccc}
\hline Bank/ Tahun & $\mathbf{2 0 1 0}$ & $\mathbf{2 0 1 1}$ & $\mathbf{2 0 1 2}$ & $\mathbf{2 0 1 3}$ & $\mathbf{2 0 1 4}$ & $\mathbf{2 0 1 5}$ & $\mathbf{2 0 1 6}$ & $\mathbf{2 0 1 7}$ \\
\hline Muamalat & 44.15 & 45.71 & 59.3 & 47.05 & 47.56 & 43.54 & 41.56 & 42.46 \\
Mega Syariah & 53.43 & 58.82 & 82.76 & 100 & 58.04 & 59.7 & 75.64 & 62.38 \\
BRI Syariah & 68.03 & 61.05 & 79.24 & 87.71 & 100 & 92.49 & 100 & 100 \\
BCA Syariah & & 72.64 & 81.68 & 66.54 & 66.69 & 66.8 & 67.25 & 81.61 \\
BNI Syariah & 100 & 59.83 & 65.84 & 97.87 & 100 & 98.18 & 100 & 100 \\
BTPN Syariah & & & & 100 & 55.31 & 61.03 & 60.79 & 69.71 \\
PDSB & 100 & 96.22 & 100 & 82.64 & 100 & 100 & 100 & 87.69 \\
Maybank Syariah & & & 100 & 100 & 100 & 100 & 100 & 100 \\
Aceh Syariah & & & & & & & 100 & 100 \\
Rata-rata BUS 2 & 73.12 & 65.71 & 81.26 & 85.23 & 78.45 & 77.72 & 82.80 & 82.65 \\
BUS & 100 & 99.84 & 100 & 100 & 81.98 & 96.96 & 97.99 & 100 \\
\hline S
\end{tabular}

Sumber: Software Banxia Frontier Analyst 4, 2019 (diolah)

Pada tahun 2010 dibuka lima BUS baru sehingga total terdapat sebelas BUS yang beroperasi di Indonesia. Kondisi ekspansi yang sangat pesat menyebabkan rasio ROA menurun dan mempengaruhi skor PTE rata-rata BUS BUKU 2 dan BUS. Rendahnya skor efisiensi PTE BUS BUKU 2 mengingat industri perbankan syariah merupakan industri yang masih muda dan baru mulai tumbuh, biaya operasional dan personalia bank syariah masih relatif tinggi (Ascarya \& Yumanita, 2006). Skor PTE rata-rata BUS BUKU 2 memiliki nilai kurang dari 100 yang artinya sebagian besar BUS dalam 
kategori BUKU 2 masih belum menjalankan kegiatannya secara efisien. Skor PTE BUS BUKU 2 lebih rendah dari industri BUS sepanjang periode pengamatan.

Tabel 2 Skor efisiensi teknis (TE) BUS BUKU 2

\begin{tabular}{ccccccccc}
\hline Bank/ Tahun & $\mathbf{2 0 1 0}$ & $\mathbf{2 0 1 1}$ & $\mathbf{2 0 1 2}$ & $\mathbf{2 0 1 3}$ & $\mathbf{2 0 1 4}$ & $\mathbf{2 0 1 5}$ & $\mathbf{2 0 1 6}$ & $\mathbf{2 0 1 7}$ \\
\hline Muamalat & 34.42 & 32.3 & 39.06 & 37.28 & 33.52 & 29.55 & 29.2 & 32.28 \\
Mega Syariah & 33.47 & 31.32 & 42.59 & 52.77 & 36.76 & 37.76 & 51.79 & 49.2 \\
BRI Syariah & 54.03 & 41.99 & 49.94 & 59.49 & 100 & 56.31 & 78.69 & 100 \\
BCA Syariah & & 62.76 & 68.9 & 62.95 & 66.19 & 64.19 & 62.68 & 75.04 \\
BNI Syariah & 100 & 38.49 & 40.33 & 51.32 & 48.69 & 50.43 & 100 & 100 \\
BTPN Syariah & & & & 100 & 38.52 & 40.12 & 39.04 & 39.06 \\
Panin Syariah & 100 & 96.1 & 100 & 82.33 & 100 & 100 & 100 & 85.84 \\
Maybank Syariah & & & 100 & 100 & 100 & 100 & 100 & 100 \\
Aceh Syariah & & & & & & & 100 & 66.42 \\
Rata-rata BUS 2 & 64.38 & 50.49 & 62.97 & 68.27 & 65.46 & 59.80 & 73.49 & 71.98 \\
BUS & 67.12 & 62.32 & 72.61 & 73.37 & 51.41 & 52.55 & 51.76 & 54.11 \\
\hline
\end{tabular}

Sumber: Software Banxia Frontier Analyst 4, 2019 (diolah)

Technical efficiency atau efisiensi teknis (TE) merupakan hasil perkalian antara PTE dan SE, sehingga skor TE sangat dipengaruhi oleh PTE. Sama halnya dengan skor PTE, skor TE rata-rata BUS BUKU 2 seluruhnya bernilai kurang 100, artinya BUS BUKU 2 secara teknis belum efisien. Pada tahun 2010-2013 skor TE BUS lebih besar dari rata-rata BUS BUKU 2, namun pada 2014-2017 menjadi lebih rendah. Hal ini menunjukkan bahwa BUS BUKU 2 lebih efisiensi secara teknis bila dibandingkan dengan industri BUS.

Tabel 3 Skor efisiensi skala (SE) BUS BUKU 2

\begin{tabular}{ccccccccc}
\hline Bank/ Tahun & $\mathbf{2 0 1 0}$ & $\mathbf{2 0 1 1}$ & $\mathbf{2 0 1 2}$ & $\mathbf{2 0 1 3}$ & $\mathbf{2 0 1 4}$ & $\mathbf{2 0 1 5}$ & $\mathbf{2 0 1 6}$ & $\mathbf{2 0 1 7}$ \\
\hline Muamalat & 77.96 & 70.66 & 65.87 & 79.23 & 70.48 & 67.87 & 70.26 & 76.02 \\
Mega Syariah & 63.02 & 53.25 & 51.46 & 52.77 & 63.34 & 63.25 & 68.47 & 78.87 \\
BRI Syariah & 79.42 & 68.78 & 63.02 & 67.83 & 100 & 60.88 & 78.69 & 100.00 \\
BCA Syariah & & 86.40 & 84.35 & 94.60 & 99.25 & 96.09 & 93.20 & 91.95 \\
BNI Syariah & 100 & 64.33 & 61.25 & 52.44 & 48.69 & 51.36 & 100 & 100 \\
BTPN Syariah & & & & 100 & 69.64 & 65.74 & 64.22 & 56.03 \\
Panin Syariah & 100 & 99.88 & 100 & 99.62 & 100 & 100 & 100 & 97.89 \\
Maybank Syariah & & & 100 & 100 & 100 & 100 & 100 & 100 \\
Aceh Syariah & & & & & & & 100 & 66.42 \\
Rata-rata BUS 2 & 84.08 & 73.88 & 75.14 & 80.81 & 81.42 & 75.65 & 86.09 & 85.24 \\
BUS & 67.12 & 62.42 & 72.61 & 73.37 & 62.71 & 54.20 & 52.82 & 54.11 \\
\hline
\end{tabular}

Sumber: Software Banxia Frontier Analyst 4, 2019 (diolah)

Skor SE rata-rata industri BUS dan BUS BUKU 2 tidak pernah mencapai skor 100. Artinya, rata-rata industri BUS dan BUS BUKU 2 belum efisien dalam kegiatannya operasionalnya.

\section{Potensi Perbaikan BUS BUKU 2}

Pada saat pengukuran efisiensi, bank dihadapkan pada kondisi bagaimana mendapatkan tingkat output yang optimal dengan tingkat input yang ada, atau mendapatkan tingkat input yang minimum dengan tingkat output tertentu. Dengan diidentifikasinya alokasi input dan output, dapat dianalisis lebih jauh untuk melihat penyebab ketidakefisienan (Mansyur, 2012). Skor efisiensi BUS BUKU 2 selalu kurang dari 100, artinya sebagian besar BUS BUKU 2 belum efisien dalam mengelola kinerjanya. BUS BUKU 2 perlu melakukan perbaikan baik dari sisi input maupun output sebagai berikut: 
Tabel 4 Potensi perbaikan efisiensi teknis murni (PTE) BUS BUKU 2

\begin{tabular}{ccccc}
\hline \multirow{3}{*}{ Input } & Minimasi Input & $\mathbf{2 0 1 3}$ & $\mathbf{2 0 1 4}$ & $\mathbf{2 0 1 7}$ \\
\hline \multirow{3}{*}{ Output } & Aset Tetap & $-0.60 \%$ & $-20.2 \%$ & $-15.39 \%$ \\
& Tenaga Kerja (Biaya) & $-2.91 \%$ & $-13.97 \%$ & $-8.82 \%$ \\
& Dana Pihak Ketiga & $-3.98 \%$ & $-12.98 \%$ & $-8.82 \%$ \\
\hline \multirow{3}{*}{ Input } & Investment & $92.50 \%$ & $27.29 \%$ & $6.12 \%$ \\
& Murabahah & $0 \%$ & $12.89 \%$ & $0 \%$ \\
\hline \multirow{3}{*}{} & Pembiayaan Bagi Hasil & $0 \%$ & $12.73 \%$ & $60.86 \%$ \\
\hline \multirow{3}{*}{ Output } & Menaga Kerja (Biaya) & $-2.37 \%$ & $-4.43 \%$ & $0 \%$ \\
& Dana Pihak Ketiga & $-3.47 \%$ & $-1.56 \%$ & $0 \%$ \\
\hline & Investment & $93.05 \%$ & $32.11 \%$ & $7.34 \%$ \\
\cline { 2 - 5 } & Membiayaan Bagi Hasil & $0.56 \%$ & $27.91 \%$ & $85.65 \%$ \\
\hline
\end{tabular}

Sumber: Software Banxia Frontier Analyst 4, 2019 (diolah)

Berdasarkan PTE tahun 2017, BUS BUKU 2 semakin efisien sehingga perbaikan hanya perlu dilakukan pada tiga variabel yaitu aset tetap, investment dan pembiayaan bagi hasil. Aset tetap perlu perbaikan dengan pengurangan sebesar $15.39 \%$. Investment perlu perbaikan dengan peningkatan sebesar $7.34 \%$. Pembiayaan bagi hasil perlu perbaikan dengan peningkatan sebesar $85.65 \%$ dan menjadi penyebab inefisiensi terbesar pada tahun 2017.

Tabel 5 Potensi perbaikan efisiensi teknis (TE) BUS BUKU 2

\begin{tabular}{|c|c|c|c|c|}
\hline & Minimasi Input & 2013 & 2014 & 2017 \\
\hline \multirow{3}{*}{ Input } & Aset Tetap & $-12.03 \%$ & $-27.49 \%$ & $-27.87 \%$ \\
\hline & Tenaga Kerja (Biaya) & $-17.16 \%$ & $-20.87 \%$ & $-12.62 \%$ \\
\hline & Dana Pihak Ketiga & $-11.32 \%$ & $-16.66 \%$ & $-11.96 \%$ \\
\hline \multirow{4}{*}{ Output } & Investment & $54.88 \%$ & $13.44 \%$ & $14.4 \%$ \\
\hline & Murabahah & $4.62 \%$ & $11.44 \%$ & $0 \%$ \\
\hline & Pembiayaan Bagi Hasil & $0 \%$ & $10.10 \%$ & $33.14 \%$ \\
\hline & Maksimasi Output & 2013 & 2014 & 2017 \\
\hline \multirow{3}{*}{ Input } & Aset Tetap & $-3.73 \%$ & $-8.51 \%$ & $-13.08 \%$ \\
\hline & Tenaga Kerja (Biaya) & $-7.12 \%$ & $-3.67 \%$ & $-0.49 \%$ \\
\hline & Dana Pihak Ketiga & $-2.71 \%$ & $-0.65 \%$ & $0 \%$ \\
\hline \multirow{3}{*}{ Output } & Investment & $62.22 \%$ & $31.79 \%$ & $23.75 \%$ \\
\hline & Murabahah & $14.02 \%$ & $28.34 \%$ & $11.58 \%$ \\
\hline & Pembiayaan Bagi Hasil & $10.19 \%$ & $27.05 \%$ & $51.1 \%$ \\
\hline
\end{tabular}

Sumber: Software Banxia Frontier Analyst 4, 2019 (diolah)

Berdasarkan TE tahun 2017, BUS BUKU 2 semakin efisien dan terdapat empat variabel yang perlu perbaikan yaitu aset tetap, biaya tenaga kerja, investment dan pembiayaan bagi hasil. Aset tetap perlu perbaikan dengan pengurangan sebesar $27.87 \%$. Biaya tenaga kerja perlu perbaikan dengan pengurangan sebesar $12.62 \%$. Investment perlu perbaikan dengan peningkatan sebesar $23.57 \%$. Pembiayaan bagi hasil perlu perbaikan dengan peningkatan sebesar $51.10 \%$. 


\section{Kinerja Keuangan dan Efisiensi PDSB Pra IPO (Tahun 2010-2013)}

Tahun 2010 PDSB fokus pada penguatan struktur organisasi untuk pemenuhan SDM terutama bidang bisnis dan pemasaran guna akselerasi pertumbuhan. Pada tahun 2011 PDSB meningkatkan pertumbuhan aset $121.68 \%$ menjadi Rp 1.02 triliun dan berhasil membukukan laba Rp 10.9 miliar. ROA PDSB yaitu $1.75 \%$ sedikit di atas ROA BUS BUKU 2 sebesar $1.49 \%$.

Pemegang saham Bank Panin melakukan penambahan modal disetor sebesar Rp 300 miliar. CAR PDSB sebesar $61.89 \%$ jauh di atas CAR BUS BUKU 2 sebesar $34.30 \%$. Perolehan CAR ini sebagai modal PDSB melakukan ekspansi dan mengembangkan usaha di tahun-tahun mendatang secara berkesinambungan.
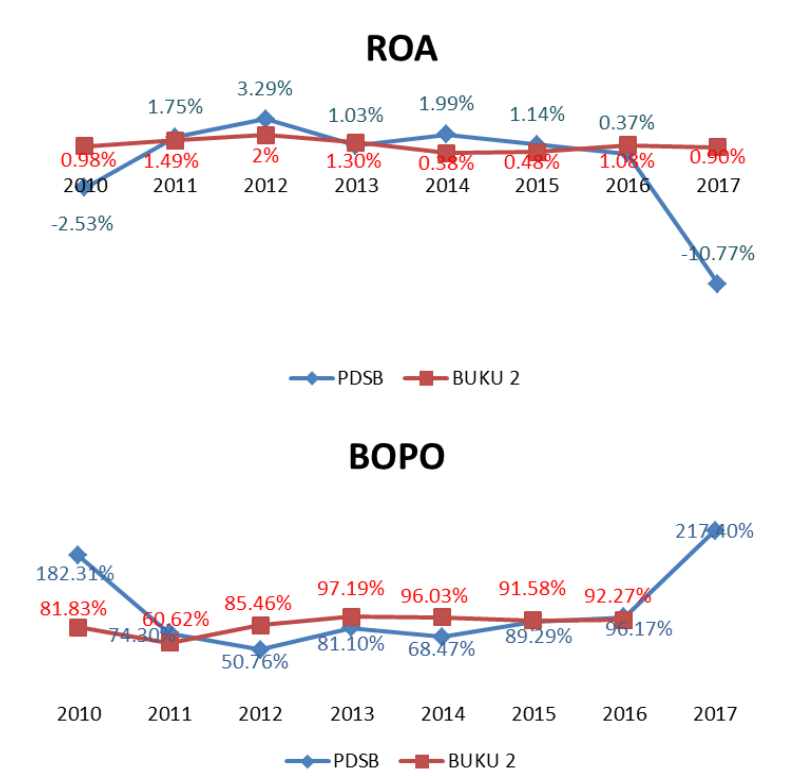

Sumber: Annual Report PDSB, 2010-2017
CAR

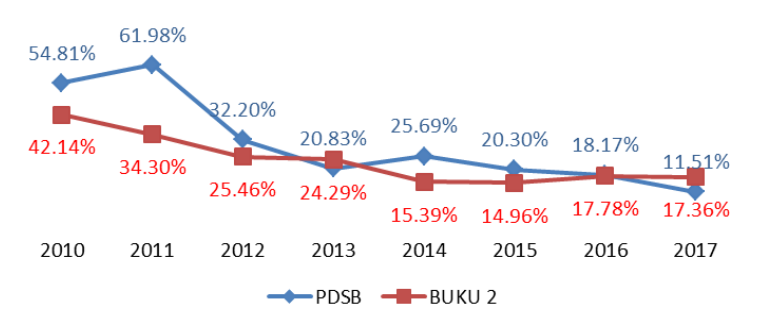

FDR

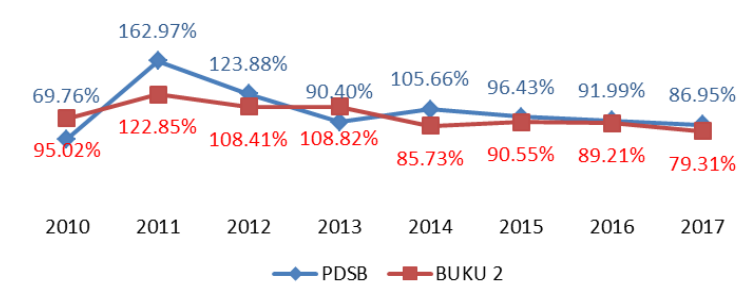

Gambar 5 ROA, CAR, BOPO, FDR tahun 2010-2017

Pada tahun 2011 PDSB dapat menjaga BOPO dengan baik di 74.30\% lebih rendah dari BOPO BUS BUKU 2 yang memiliki nilai sebesar $81.83 \%$. Pertumbuhan pembiayaan sebesar $216.76 \%$ yang lebih besar dibandingkan pertumbuhan DPK sebesar 35.51\% mengakibatkan FDR PDSB sangat tinggi yaitu $162.97 \%$. Skor efisiensi semula 100 (efisien) mengalami sedikit penurunan baik PTE maupun TE.

Pada tahun 2012, kondisi perekonomian Indonesia yang stabil berpengaruh positif pada pertumbuhan aset BUS sebesar 26.21\%. Aset PDSB tumbuh $110.13 \%$ menjadi Rp 2.13 triliun dan laba meningkat menjadi Rp 37.09 miliar. ROA PDSB meningkat menjadi 2\%. Pencapaian laba mengindikasikan kinerja PDSB semakin baik melalui peningkatan penyaluran pembiayaan yang diberikan pada sektor aman dan memberikan kontribusi pendapatan operasional yang cukup signifikan. PDSB mampu melakukan efisiensi biaya operasional dan optimalisasi pendapatan operasional sehingga BOPO turun menjadi 50.76\%, perusahaan semakin efisien dengan skor 100. Tahun 2011-2012 PDSB mampu menjaga BOPO dengan baik dan lebih rendah dari BOPO BUS BUKU 2.

Bank Panin kembali melakukan penambahan modal disetor sehingga total modal menjadi Rp 449.52 miliar. CAR PDSB sebesar 32.20\% menurun dari tahun 2011 namun tetap lebih tinggi dari CAR BUS BUKU 2. Pertumbuhan DPK yang optimal berdampak pada penurunan FDR menjadi $123.88 \%$. 


\section{Efisiensi PDSB}

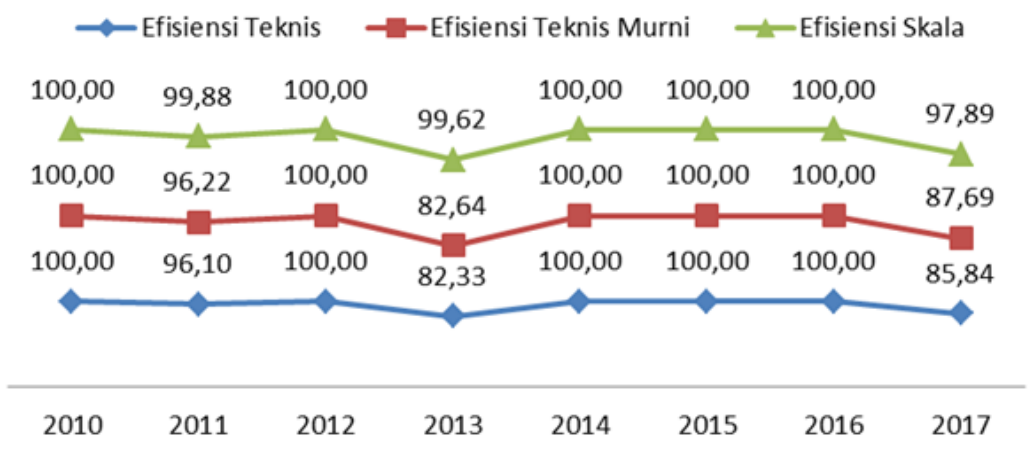

Sumber: Software Banxia Frontier Analyst 4, 2019 (diolah)

Gambar 6 Efisiensi PDSB tahun 2010-2017

Tahun 2013 pertumbuhan ekonomi melambat di bawah level 6\%. BUS untuk pertama kali sejak diperkenalkan mengalami perlambatan pertumbuhan secara year on year yaitu $22.21 \%$ dari tahun sebelumnya $26.21 \%$. Kondisi ini berpengaruh pada PDSB di mana pertumbuhan aset $89 \%$, pembiayaan dan DPK masih tumbuh masing-masing $71.3 \%$ dan $135 \%$ walaupun pertumbuhannya tidak setinggi tahun-tahun sebelumnya. BOPO mengalami peningkatan menjadi $81.10 \%$ dan skor efisiensi menurun, TE menjadi 82.33, PTE menjadi 82.64 dan SE menjadi 99.62.

Tabel 6 Efisiensi PDSB, rata-rata BUS BUKU 2 dan BUS tahun 2010-2013

\begin{tabular}{lcccc}
\hline \multicolumn{1}{c}{ Tahun } & $\mathbf{2 0 1 0}$ & $\mathbf{2 0 1 1}$ & $\mathbf{2 0 1 2}$ & $\mathbf{2 0 1 3}$ \\
\hline PDSB & \multicolumn{5}{c}{ Efisiensi Teknis (TE) } \\
Rata-rata BUS BUKU 2 & 64.38 & 50.49 & 62.97 & 68.27 \\
BUS & 67.12 & 62.32 & 72.61 & 73.37 \\
\hline \multicolumn{4}{c}{ Efisiensi Teknis Murni (PTE) } \\
\hline PDSB & 100 & 96.22 & 100 & 82.64 \\
Rata-rata BUS BUKU 2 & 73.12 & 65.71 & 81.26 & 85.23 \\
BUS & 100 & 99.84 & 100 & 100 \\
\hline & \multicolumn{5}{c}{ Efisiensi Skala (SE) } \\
\hline PDSB & 100 & 99.88 & 100 & 99.62 \\
Rata-rata BUS BUKU 2 & 84.08 & 73.88 & 75.14 & 80.81 \\
BUS & 67.12 & 62.42 & 72.61 & 73.37 \\
\hline
\end{tabular}

Sumber: Software Banxia Frontier Analyst 4, 2019 (diolah)

Meskipun skor efisiensi dalam periode pra IPO tahun 2010-2013 bersifat fluktuatif, dapat disimpulkan bahwa PDSB lebih efisien dari BUS BUKU 2 maupun agregat BUS. Hal ini dapat dibuktikan dengan skor efisiensi pra IPO PDSB selalu di atas skor efisiensi rata-rata BUS BUKU 2 maupun agregat BUS (kecuali PTE tahun 2011 dan 2013).

\section{Kinerja Keuangan PDSB Pasca IPO (Tahun 2014-2017)}

Rasio keuangan PDSB selama tiga tahun terakhir yaitu CAR, ROA, NPF, dan BOPO selalu lebih baik dari rata-rata kinerja BUS BUKU 2. Hal ini menjadi landasan PDSB untuk melakukan penawaran saham kepada publik melalui IPO. PDSB melaporkan total dana yang berhasil dihimpun dari IPO sebesar Rp 468.64 miliar dengan realisasi penggunaan dana 80\% atau sebesar Rp 374.11 miliar untuk memperkuat struktur pendanaan jangka panjang dalam rangka ekspansi pembiayaan dan $20 \%$ atau sebesar Rp 93.53 miliar untuk pengembangan jaringan dan infrastruktur. 
Pada tahun-tahun sebelumnya PDSB berfokus pada segmen ritel dan menengah. Sejak tahun 2014, PDSB merubah segmen fokus dan menyalurkan pembiayaan ke tiga segmen pasar utama yakni usaha kecil, komersial (menengah dan besar) serta korporasi. PDSB juga mengalihkan fokus bisnis pembiayaan dari yang sebelumnya pembiayaan berbasis jual beli (murabahah) menjadi pembiayaan bagi hasil. Keputusan ini diambil untuk mengantisipasi melambatnya pertumbuhan ekonomi sektor riil akibat kenaikan suku bunga acuan BI. Pertumbuhan pembiayaan meningkat sebesar $83.44 \%$ menjadi Rp 4.73 triliun. Pertumbuhan pembiayaan yang lebih tinggi dari DPK menyebabkan FDR tahun 2014 meningkat menjadi 105.66\%. Sebaliknya BUS BUKU 2 justru mengalami penurunan FDR menjadi $101.61 \%$.

Laba tahun 2014 meningkat 230\% dari tahun 2013 menjadi Rp 70.93 miliar sehingga ROA PDSB mengalami peningkatan menjadi 1.99\%. Pada tahun 2011-2012 CAR PDSB lebih baik dari CAR BUS BUKU 2, namun pada tahun 2013-2014 menjadi lebih rendah. Meskipun demikian, baik PDSB maupun BUS BUKU 2 sama-sama mengalami peningkatan CAR.

Selama tahun 2011-2013 BOPO PDSB lebih rendah dari BOPO BUS BUKU 2. Di tahun 2014 BOPO keduanya sama-sama mengalami peningkatan, namun BOPO PDSB meningkat lebih tinggi menjadi $68.47 \%$. PDSB mampu menurunkan kolektibilitas dari $1.02 \%$ menjadi $0.53 \%$ yang menunjukkan tidak ada penurunan pendapatan operasional penyaluran pembiayaan. Penurunan BOPO lebih disebabkan oleh meningkatnya biaya operasional. Skor efisiensi PDSB meningkat menjadi 100 (efisien).

Tabel 7 Efisiensi PDSB, rata-rata BUS BUKU 2 dan BUS tahun 2014-2017
\begin{tabular}{lcccc}
\hline Tahun & $\mathbf{2 0 1 4}$ & $\mathbf{2 0 1 5}$ & $\mathbf{2 0 1 6}$ & $\mathbf{2 0 1 7}$ \\
\hline & \multicolumn{4}{c}{ Efisiensi Teknis (TE) } \\
\hline PDSB & 100 & 100 & 100 & 85.8 \\
Rata-rata BUS BUKU 2 & 65.46 & 59.80 & 73.49 & 71.98 \\
BUS & 51.41 & 52.55 & 51.76 & 54.11 \\
\hline \multicolumn{5}{c}{ Efisiensi Teknis Murni (PTE) } \\
\hline PDSB & 100 & 100 & 100 & 87.69 \\
Rata-rata BUS BUKU 2 & 78.45 & 77.72 & 82.80 & 82.65 \\
BUS & 81.98 & 96.96 & 97.99 & 100 \\
\hline & \multicolumn{4}{c}{ Efisiensi Skala } \\
\hline PDSB & 100 & 100 & 100 & 97.89 \\
Rata-rata BUS BUKU 2 & 74.08 & 67.34 & 79.03 & 78.97 \\
BUS & 62.71 & 54.20 & 52.82 & 54.11 \\
\hline Sumber: Software Banxia Frontier Analyst 4.2019 (diolah)
\end{tabular}

Tahun 2015 perekonomian Indonesia terkena tekanan cukup hebat yaitu melemahnya daya beli masyarakat yang menyebabkan pertumbuhan ekonomi menurun. Aset, pembiayaan dan DPK PDSB tetap tumbuh meskipun tidak setinggi tahun-tahun sebelumnya. Kondisi perekonomian menyebabkan penurunan laba PDSB menjadi Rp 75.37 miliar.

ROA dan CAR PDSB tahun 2014-2015 keduanya mengalami penurunan cukup signifikan. ROA 1.90\% (tahun 2014) menjadi 1.14\% (tahun 2015) dan CAR 25.69\% (tahun 2014) menjadi $20.30 \%$ (tahun 2015), sehingga lebih rendah dari ROA dan CAR BUS BUKU 2. Sedangkan BOPO dan FDR PDSB mengalami penurunan dan lebih baik dari BUS BUKU 2 yang mengindikasikan manajemen PDSB tetap efisien dalam mengatur biaya operasional serta rasio penyaluran pembiayaannya. Skor efisiensi PDSB stabil di nilai 100 (efisien), skor ini berbeda dengan skor efisiensi rata-rata BUS BUKU 2 dan BUS yang mengalami penurunan.

Pertumbuhan aset PDSB tahun 2016 sebesar $22.82 \%$ menjadi Rp 8.76 triliun, pertumbuhan ini lebih tinggi dari pertumbuhan aset BUS namun tidak setinggi tahun-tahun sebelumnya. Demikian halnya dengan pembiayaan dan DPK juga mengalami tren penurunan pertumbuhan sejak tahun 2015. Laba turun 74\% menjadi Rp 19.54 miliar. Penurunan laba disebabkan oleh kebijakan penyediaan cadangan 
Penyisihan Penghapusan Aktiva Produktif (PPAP) sesuai ketentuan. Faktor lain yaitu tingginya beban operasional dan biaya modal akibat pembukaan kantor baru. Penurunan laba menyebabkan ROA turun menjadi $0.37 \%$ jauh tertinggal dari ROA BUS BUKU 2 yang meningkat di angka $3.08 \%$. CAR PDSB mengalami penurunan hingga menyentuh angka $18.17 \%$.

Dari sisi BOPO PDSB mampu menjaga rasio BOPO di angka 96.17\%. BOPO dan FDR PDSB mengalami penurunan dan lebih baik dari BUS BUKU 2, yang menunjukkan meskipun di tengah kondisi sulit manajemen PDSB mampu menjaga efisiensi (skor efisiensi 100) dan mengatur rasio penyaluran pembiayaannya. Skor efisiensi PDSB stabil di angka 100 dan konsisten lebih baik dari skor efisiensi rata-rata BUS BUKU 2 dan BUS yang tengah mengalami peningkatan dari skor tahun 2015.

Tahun 2017 PDSB belum mampu melakukan recovery atas penurunan kualitas pembiayaan. NPF Nett tercatat di angka $4.83 \%$. Kinerja bank terpengaruh hingga hampir seluruh indikator keuangan mengalami penurunan. Aset PDSB turun sebesar 1.47\% menjadi Rp 8.63 triliun bertolak belakang dengan pertumbuhan aset BUS sebesar $13.31 \%$. Dengan menurunnya kolektibilitas 2 ke kolektibilitas 3 dan 4, di tahun 2017 BUS terkena tambahan beban PPAP sehingga membukukan kerugian Rp 968.85 miliar yang berakibat pada penurunan modal bank.

Berdasarkan indepth interview dengan manajemen PDSB, segmen komersial dan korporasi merupakan penyumbang utama dari penurunan kualitas pembiayaan yang terjadi. PDSB mulai terjun pada penyaluran pembiayaan segmen korporasi pada tahun 2014 yang merupakan tahun pelaksanaan IPO. Segmen komersial dengan limit pembiayaan lebih dari Rp 10 miliar dan segmen korporat dengan limit pembiayaan Rp 10-30 miliar awalnya dipandang manajemen PDSB sebagai booster untuk meningkatkan aset perusahaan. Peningkatan portofolio pembiayaan belum diimbangi dengan peningkatan kapabilitas SDM selaku pengelola sehingga terjadi loss pada penyaluran pembiayaan di segmen ini. Upaya recovery pembiayaan bermasalah juga diikuti dengan pembatasan laju pertumbuhan pembiayaan komersial dan korporasi.

ROA turun sebagai dampak dari kerugian dan penurunan modal hingga menyentuh posisi minus yaitu $-10.71 \%$. Kecukupan modal yang digambarkan oleh CAR juga turun menjadi $11.71 \%$. BOPO meningkat menjadi $217.40 \%$ sebagai dampak dari proses konsolidasi dan transformasi yang terjadi. Pembukuan kerugian ROA, CAR dan BOPO PDSB ini menjadi yang terendah dan terburuk dalam sejarah Bank Umum Syariah.

Penurunan skor efisiensi juga terjadi di tengah memburuknya kinerja keuangan PDSB, dengan skor TE 85.84, PTE 87.69 dan SE 97.89. Penurunan skor efisiensi juga terjadi pada BUS BUKU 2 lainnya. Sedangkan agregat BUS justru menunjukkan peningkatan skor efisiensi. Di tengah penurunan skor efisiensi yang terjadi, PDSB masih lebih efisien dibandingkan skor efisiensi rata-rata BUS BUKU 2 dan agregat BUS sepanjang periode pasca IPO tahun 2014-2017.

Perolehan skor efisiensi PDSB yang selalu di atas rata-rata BUS BUKU 2 tidak dapat dipisahkan dari pengambilan kebijakan strategis yang dilakukan oleh jajaran pengurus PDSB. Penelitian Zeineb \& Mensi (2018) menunjukkan struktur kepengurusan bank syariah mempengaruhi cara pengambilan keputusan, di mana pengambilan keputusan dengan risiko tinggi memiliki hubungan positif dalam mencapai tingkat efisiensi bank yang lebih baik.

Salah satu kebijakan jajaran pengurus adalah terkait pelaksanaan IPO PDSB yang meningkatkan efisiensi secara signifikan setelah go public daripada bank lain yang tidak melakukan IPO, namun tidak menunjukkan efisiensi PDSB dalam jangka panjang. Hal lain yang perlu diperhatikan yaitu kepemilikan saham publik di PDSB hanya berkisar 17\% sehingga kinerja keuangan yang dilaporkan tidak sepenuhnya dapat menggambarkan kinerja perusahaan karena pengambilan kebijakan didominasi oleh pemegang saham pengendali. 


\section{Potensi Perbaikan PDSB}

Berdasarkan TE pra IPO PDSB tahun 2017, pembiayaan murabahah menjadi penyebab inefisiensi terbesar sehingga perlu perbaikan dengan peningkatan sebesar $41.3 \%$.

Tabel 8 Potensi perbaikan PDSB

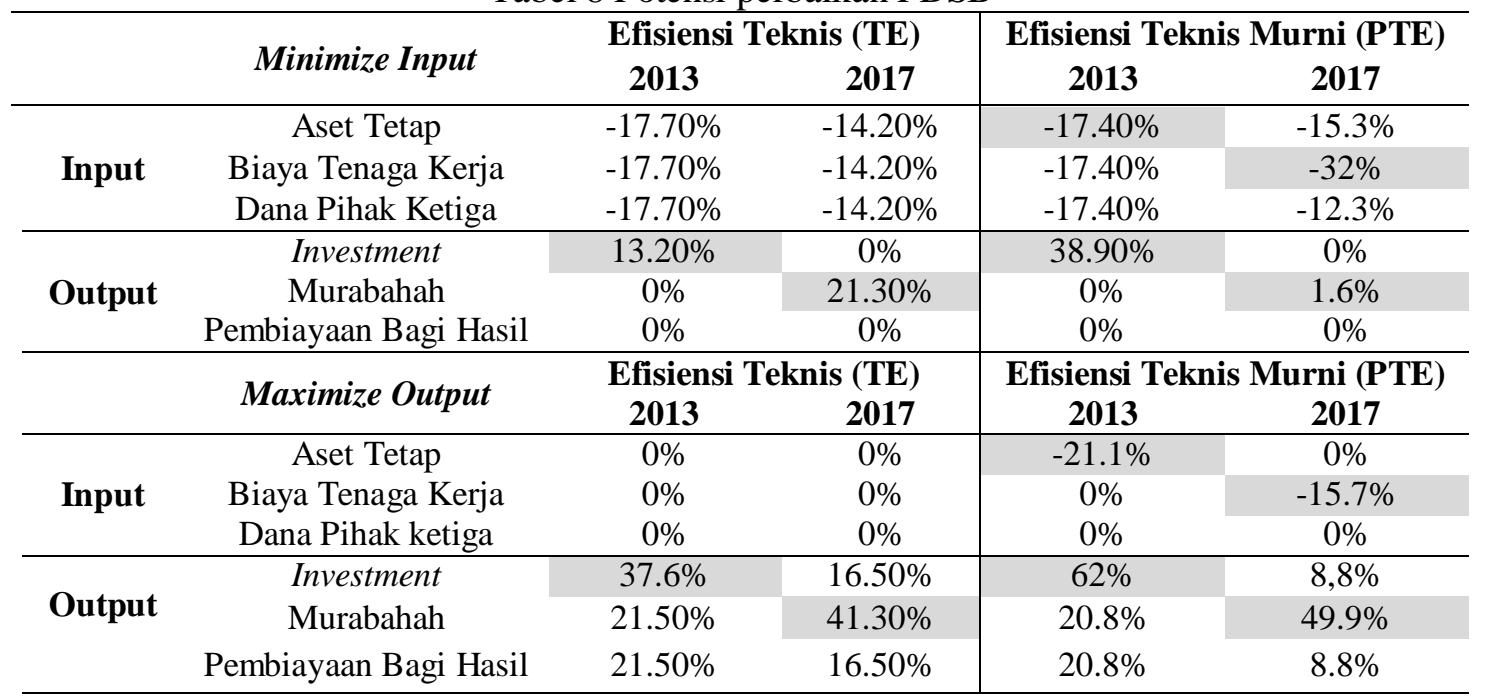

Sumber: Software Banxia Frontier Analyst 4, 2019 (diolah)

Berdasarkan PTE pra IPO tahun 2017, perbaikan dilakukan pada dua variabel yaitu biaya tenaga kerja dan pembiayaan murabahah. Biaya tenaga kerja perlu perbaikan dengan pengurangan sebesar $32 \%$. Tingginya biaya tenaga kerja menjadi penyebab inefisiensi terbesar. Pembiayaan murabahah perlu perbaikan dengan peningkatan sebesar $49.9 \%$.

\section{PDSB Pra IPO vs PDSB Pasca IPO}

Hasil uji-T pada Tabel 9 menguji beda rata-rata parameter PDSB pra IPO dan PDSB pasca IPO. Perbedaan signifikan hanya terjadi pada parameter CAR dimana perolehan CAR pra IPO PDSB mengindikasikan lebih baik dibandingkan CAR pasca IPO PDSB.

Tabel 9 Hasil uji beda PDSB pra IPO vs PDSB pasca IPO

\begin{tabular}{|c|c|c|c|c|c|c|c|}
\hline Variabel & IPO & $\mathbf{N}$ & Mean & $\begin{array}{c}\text { Std. } \\
\text { Deviation }\end{array}$ & $\mathbf{t}$ & df & $\begin{array}{l}\text { Sig. (2- } \\
\text { tailed) }\end{array}$ \\
\hline \multirow{2}{*}{ Efisiensi TE } & Pra & 4 & 94.607500 & 8.3889347 & \multirow{2}{*}{-.338} & \multirow{2}{*}{6} & \multirow{2}{*}{.747} \\
\hline & Pasca & 4 & 96.460000 & 7.0800000 & & & \\
\hline \multirow{2}{*}{ Efisiensi PTE } & Pra & 4 & 94.715000 & 8.2448590 & \multirow{2}{*}{-.429} & \multirow{2}{*}{7} & \multirow{2}{*}{.683} \\
\hline & Pasca & 4 & 96.922500 & 6.1550000 & & & \\
\hline \multirow{2}{*}{ Efisiensi SE } & Pra & 4 & 99.875000 & .1791647 & \multirow{2}{*}{.752} & \multirow{2}{*}{8} & \multirow{2}{*}{.480} \\
\hline & Pasca & 4 & 99.472500 & 1.0550000 & & & \\
\hline \multirow{2}{*}{ ROA } & Pra & 4 & .008850 & .0246411 & \multirow{2}{*}{.833} & \multirow{2}{*}{9} & \multirow{2}{*}{.437} \\
\hline & Pasca & 4 & -.018175 & .0600489 & & & \\
\hline \multirow{2}{*}{ BOPO } & Pra & 4 & .971175 & .5826371 & \multirow{2}{*}{-.465} & \multirow{2}{*}{11} & \multirow{2}{*}{.658} \\
\hline & Pasca & 4 & 1.178325 & .6741484 & & & \\
\hline \multirow{2}{*}{ CAR } & Pra & 4 & .424550 & .1920657 & \multirow{2}{*}{2.344} & \multirow{2}{*}{12} & \multirow{2}{*}{$.058 * *$} \\
\hline & Pasca & 4 & .189175 & .0586538 & & & \\
\hline \multirow{2}{*}{ NPF } & Pra & 4 & .004450 & .0041203 & - & \multirow{2}{*}{13} & \multirow{2}{*}{.115} \\
\hline & Pasca & 4 & .022300 & .0189249 & 1.843 & & \\
\hline \multirow{2}{*}{ FDR } & Pra & 4 & 1.117525 & .4078238 & \multirow{2}{*}{.794} & \multirow{2}{*}{14} & \multirow{2}{*}{.457} \\
\hline & Pasca & 4 & .952575 & .0794309 & & & \\
\hline
\end{tabular}

Keterangan: **) signifikan pada level $10 \%$

Sumber: SPSS, 2019 (diolah) 


\section{BUS BUKU 2 vs PDSB Pra IPO}

Hasil uji-T Tabel 10 menguji beda rata-rata parameter BUS BUKU 2 dan PDSB periode pra IPO. Terdapat perbedaan signifikan pada parameter efisiensi TE, PTE dan SE PDSB yang memiliki nilai lebih tinggi sehingga lebih efisien daripada BUS BUKU 2. NPF PDSB memiliki nilai lebih rendah dibandingkan BUS BUKU 2. CAR PDSB memiliki nilai lebih tinggi dibandingkan BUS BUKU 2.

Tabel 10 Hasil uji beda PDSB vs BUS BUKU 2 pra IPO

\begin{tabular}{|c|c|c|c|c|c|c|c|}
\hline Variabel & Bank & $\mathbf{N}$ & Mean & $\begin{array}{c}\text { Std. } \\
\text { Deviation }\end{array}$ & $\mathbf{t}$ & df & $\begin{array}{l}\text { Sig. (2- } \\
\text { tailed) }\end{array}$ \\
\hline \multirow{2}{*}{ Efisiensi TE } & PDSB & 4 & 94.608 & 8.389 & \multirow{2}{*}{5.975} & \multirow{2}{*}{6} & \multirow{2}{*}{$0.001 * *$} \\
\hline & BUS2 & 4 & 55.000 & 10.265 & & & \\
\hline \multirow{2}{*}{ Efisiensi PTE } & PDSB & 4 & 94.633 & 8.346 & \multirow{2}{*}{1.990} & \multirow{2}{*}{6} & \multirow{2}{*}{$0.094 * *$} \\
\hline & BUS2 & 4 & 79.500 & 12.715 & & & \\
\hline \multirow{2}{*}{ Efisiensi SE } & PDSB & 4 & 99.970 & 0.053 & \multirow{2}{*}{22.581} & \multirow{2}{*}{6} & \multirow{2}{*}{$0.000 * *$} \\
\hline & BUS2 & 4 & 68,575 & 2.780 & & & \\
\hline \multirow{2}{*}{ ROA } & PDSB & 4 & .885 & 2.464 & \multirow{2}{*}{.300} & \multirow{2}{*}{6} & \multirow{2}{*}{.774} \\
\hline & BUS2 & 4 & 1.258 & .337 & & & \\
\hline \multirow{2}{*}{ BOPO } & PDSB & 4 & 97.118 & 58.264 & \multirow[b]{2}{*}{-.490} & \multirow[b]{2}{*}{6} & \multirow{2}{*}{.641} \\
\hline & BUS2 & 4 & 82.467 & 13.425 & & & \\
\hline \multirow[b]{2}{*}{ NPF } & PDSB & 4 & .445 & .412 & \multirow[b]{2}{*}{4.311} & \multirow[b]{2}{*}{6} & \multirow[b]{2}{*}{$.005^{* *}$} \\
\hline & BUS2 & 4 & 2.007 & .596 & & & \\
\hline \multirow{2}{*}{ CAR } & PDSB & 4 & 42.455 & 19.207 & \multirow{2}{*}{-2.093} & \multirow{2}{*}{6} & \multirow{2}{*}{$.081 * *$} \\
\hline & BUS2 & 4 & 22.114 & 3.014 & & & \\
\hline \multirow{2}{*}{ FDR } & PDSB & 4 & 111.753 & 40.782 & \multirow{2}{*}{-.757} & \multirow{2}{*}{6} & \multirow{2}{*}{.478} \\
\hline & BUS2 & 4 & 95.216 & 15.672 & & & \\
\hline
\end{tabular}

\section{BUS BUKU 2 vs PDSB Pasca IPO}

Hasil uji-T Tabel 11 menguji beda rata-rata parameter BUS BUKU 2 dan PDSB periode pasca IPO dan terdapat perbedaan signifikan hanya pada parameter efisiensi TE dan SE. Efisiensi TE dan SE PDSB memiliki nilai lebih tinggi sehingga lebih efisien daripada BUS BUKU 2.

Tabel 11 Hasil uji beda BUS BUKU 2 vs PDSB pasca IPO

\begin{tabular}{|c|c|c|c|c|c|c|c|}
\hline Variabel & Bank & $\mathbf{N}$ & Mean & $\begin{array}{c}\text { Std. } \\
\text { Deviation }\end{array}$ & $\mathbf{t}$ & df & $\begin{array}{l}\text { Sig. (2- } \\
\text { tailed) }\end{array}$ \\
\hline \multirow{2}{*}{ Efisiensi TE } & PDSB & 4 & 96.460 & 7.080 & \multirow{2}{*}{6.672} & \multirow{2}{*}{6} & \multirow{2}{*}{$0.001 * *$} \\
\hline & BUS2 & 4 & 62.825 & 7.178 & & & \\
\hline \multirow{2}{*}{ Efisiensi PTE } & PDSB & 4 & 96.923 & 6.155 & \multirow{2}{*}{1.413} & \multirow{2}{*}{6} & \multirow{2}{*}{0.207} \\
\hline & BUS2 & 4 & 92.250 & 2.415 & & & \\
\hline \multirow{2}{*}{ Efisiensi SE } & PDSB & 4 & 99.473 & 1.055 & \multirow{2}{*}{10.340} & \multirow{2}{*}{6} & \multirow{2}{*}{$0.000 * *$} \\
\hline & BUS2 & 4 & 68.100 & 5.976 & & & \\
\hline \multirow{2}{*}{ ROA } & PDSB & 4 & -1.8175 & 6.0049 & \multirow{2}{*}{1.538} & \multirow{2}{*}{6} & \multirow{2}{*}{.175} \\
\hline & BUKU 2 & 4 & 2.8969 & 1.2396 & & & \\
\hline \multirow{2}{*}{ BOPO } & PDSB & 4 & 117.8325 & 67.4148 & \multirow{2}{*}{-.652} & \multirow{2}{*}{6} & \multirow{2}{*}{.539} \\
\hline & BUKU 2 & 4 & 95.7329 & 7.4215 & & & \\
\hline \multirow{2}{*}{ NPF } & PDSB & 4 & 2.2300 & 1.8925 & \multirow{2}{*}{.005} & \multirow{2}{*}{6} & \multirow{2}{*}{.997} \\
\hline & BUKU 2 & 4 & 2.2345 & .5340 & & & \\
\hline \multirow{2}{*}{ CAR } & PDSB & 4 & 18.9175 & 5.8654 & \multirow{2}{*}{1.648} & \multirow{2}{*}{6} & \multirow{2}{*}{.150} \\
\hline & BUKU 2 & 4 & 24.5743 & 3.5644 & & & \\
\hline \multirow{2}{*}{ FDR } & PDSB & 4 & 95.2575 & 7.9431 & \multirow{2}{*}{-.351} & \multirow{2}{*}{6} & \multirow{2}{*}{.737} \\
\hline & BUKU 2 & 4 & 93.3142 & 7.6988 & & & \\
\hline
\end{tabular}




\section{BUS BUKU 2}

CAR BUS BUKU 2 selalu diatas CAR perbankan syariah. Arah pergerakan CAR perbankan syariah dan BUS BUKU 2 hampir sama kecuali pada masa krisis. CAR yang meningkat menggambarkan kondisi pertumbuhan yang lebih tinggi dibandingkan pertumbuhan ATMR. Sebagai contoh pada tahun 2016 perbaikan nilai CAR didorong oleh aksi korporasi beberapa bank syariah yang menambahkan modal disetor dan penerbitan sukuk korporasi pada tahun 2016.

ROA perbankan syariah mengalami penurunan pada krisis tahun 2008. ROA kembali mengalami penurunan pada tahun 2014 dan merupakan ROA terendah dalam 10 tahun terakhir. Sejak tahun 2014 ROA perbankan syariah selalu kurang dari 1\%. ROA BUS BUKU 2 semula $3.08 \%$ pada tahun 2016 menurun tajam menjadi $0.71 \%$ pada tahun 2017. Penurunan ROA BUS BUKU 2 merupakan kontribusi salah satu BUS yaitu PDSB yang mengalami penurunan ROA hingga menyentuh angka minus yang akhirnya mempengaruhi ROA BUS BUKU 2 secara keseluruhan.

Sejak tahun 2012 BOPO perbankan syariah termasuk BUS BUKU 2 mengalami tren meningkat. Pada tahun 2014 BOPO perbankan syariah semakin tinggi menyentuh angka lebih dari $90 \%$ yang mengindikasikan penurunan efisiensi BUS akibat peningkatan biaya operasional dan atau penurunan pendapatan operasional.

Perbaikan kondisi perekonomian pasca krisis tahun 2015 merupakan faktor penting yang mempengaruhi kinerja keuangan dan efisiensi industri perbankan nasional. Perbankan syariah termasuk BUS BUKU 2 mencatatkan pertumbuhan di tahun 2016 dan 2017, walaupun tidak setinggi pertumbuhan pada tahun-tahun sebelumnya. Pertumbuhan diikuti dengan peningkatan skor efisiensi tahun 2016 dan 2017. Hasil ini sejalan dengan penelitian Fatmala (2018) yang membandingkan nilai efisiensi rata-rata sebelum dan setelah krisis tahun 2008. Nilai efisiensi rata-rata sebelum krisis 0.806 mengalami peningkatan setelah krisis keuangan menjadi 0.812 .

Skor PTE rata-rata BUS BUKU 2 selalu lebih rendah dari agregat BUS sepanjang tahun 2010-2017. Skor efisiensi rata-rata BUS BUKU 2 tidak pernah mencapai skor 100. Artinya, rata-rata BUS BUKU 2 belum efisien dalam kegiatannya operasionalnya. Pembiayaan bagi hasil (berdasarkan TE dan PTE) menjadi menjadi penyebab inefisiensi terbesar pada tahun 2017.

Hasil ini mendekati hasil penelitian yang dilakukan Puteh, Rasyidin \& Mawaddah (2017) yang memeriksa skor efisiensi lima bank syariah periode tahun 2012-2016. Hasil penelitian menyebutkan bahwa sepanjang tahun 2012-2016 perbankan syariah di Indonesia tidak efisien. Penelitian Karimah (2016) juga menunjukkan hal yang sama yaitu Bank Umum Syariah di Indonesia belum beroperasi secara efisien jika dilihat dari skor estimasi efisiensi dengan metode DEA dan SFA yang besarnya kurang dari satu.

Hasil penelitian menunjukkan keragaman skor efisiensi antar BUS BUKU 2. Kondisi ini sejalan dengan penelitian Hassan, Mohamad \& Bader (2009) yang menunjukkan bahwa tidak ada perbedaan signifikan skor efisiensi pada berbagai ukuran dan tingkat umur perusahaan. Sebagai contoh, Bank Muamalat yang merupakan bank syariah pertama di Indonesia yang didirikan pada tahun 1991 tidak pernah mencapai skor efisien. Sedangkan Maybank Syariah yang baru hadir pada tahun 2012 berhasil mencapai skor efisien selama enam tahun berturut-turut.

Skor efisiensi BNI Syariah (anak perusahaan dari Bank BNI) pada tahun 2016 dan 2017 berturut-turut memperoleh skor 100, sehingga lebih efisien dibandingkan BUS BUKU 2 lainnya. Kondisi ini sejalan dengan hasil penelitian Hadad et al. (2003) bahwa kinerja manajemen dapat dipengaruhi oleh intervensi pemilik dan manajemen yang dapat bertindak tidak semata-mata untuk kepentingan pemilik walaupun tujuannya untuk memaksimalkan keuntungan. Dari jenis kepemilikan, bank syariah milik pemerintah lebih efisien dibandingkan dengan bank syariah swasta (Nurwati, 2014). 
Said (2013) mengukur skor efisiensi bank syariah di kawasan MENA dan Afrika Utara dan menemukan bahwa rata-rata bank syariah mengalami kondisi tidak efisien secara teknis selama krisis finansial tahun 2007-2009. Kondisi tersebut sejalan dengan hasil penelitian ini yang menunjukkan bahwa BUS BUKU 2 mengalami kondisi tidak efisien secara teknis pada krisis tahun 2015. Mezzi (2018) mengukur skor efisiensi di daerah Timur Tengah tahun 2010-2012. Dari hasil penelitian tersebut diketahui bahwa arah peningkatan atau penurunan rata-rata skor efisiensi bank syariah di Timur Tengah sama dengan BUS BUKU 2 pada tahun 2010-2012.

Majeed \& Zanib (2016) mengukur skor efisiensi di Pakistan tahun 2007-2014. Dari hasil penelitian tersebut diketahui bahwa arah peningkatan atau penurunan rata-rata skor efisiensi bank syariah di Pakistan sama dengan BUS BUKU 2 pada tahun 2010-2014. Dari tiga penelitian tersebut dapat disampaikan bahwa kondisi efisiensi BUS BUKU 2 tidak berbeda dengan yang dialami oleh bank syariah di luar negeri sebagai dampak dari kondisi perekonomian global..

\section{Panin Dubai Syariah Bank}

Meskipun di tengah ketidakpastian perekonomian global yang terjadi di tahun 2013, manajemen PDSB mampu mengelola perusahaan dengan sangat baik yang dibuktikan dengan rasio keuangan PDSB selama tahun 2011-2013 yaitu CAR, ROA, NPF, dan BOPO selalu lebih baik dari rata-rata kinerja BUS BUKU 2. Hal ini menjadi dasar bagi PDSB melaksanakan IPO.

Satu tahun pasca pelaksanaan IPO yaitu tahun 2015, perekonomian Indonesia terkena tekanan cukup hebat sehingga pertumbuhan ekonomi menurun menjadi $4.88 \%$. Sebagai salah satu dampaknya PDSB mengalami penurunan pertumbuhan aset, pembiayaan dan DPK serta rasio ROA dan CAR.

Tahun 2016 perekonomian Indonesia mulai membaik dan tumbuh menjadi 5.02\%, namun PDSB masih mengalami penurunan pertumbuhan. Laba turun $74 \%$ menjadi Rp 19.54 miliar yang disebabkan oleh kebijakan penyediaan cadangan Penyisihan Penghapusan Aktiva Produktif (PPAP) sesuai ketentuan. Faktor lain yaitu tingginya beban operasional dan biaya modal akibat pembukaan kantor baru. ROA dan CAR PDSB mengalami penurunan sementara ROA dan CAR BUS BUKU 2 mengalami peningkatan. Sedangkan BOPO dan FDR PDSB mengalami penurunan dan lebih baik dari BUS BUKU 2 menunjukkan PDSB tetap mampu menjaga efisiensi dan mengatur rasio penyaluran pembiayaannya.

Peningkatan nilai efisiensi pasca IPO tahun 2014 hingga 2016 senada dengan penelitian Yin, Yang \& Mehran (2015). Hasil penelitian menunjukkan bahwa terdapat efek seleksi yang kuat. Artinya, bank yang memilih untuk go public secara signifikan lebih efisien daripada yang tidak. Namun, analisis efek dinamis tidak menunjukkan bukti bahwa efisiensi bank meningkat setelah go public, baik dalam jangka pendek atau dalam jangka panjang.

Tahun 2017 dicanangkan sebagai tahun konsolidasi dan transformasi PDSB. FDR menurun menjadi 86.95\% dan PDSB belum mampu melakukan recovery atas penurunan kualitas pembiayaan (khususnya di segmen komersil dan korporasi) dengan NPF Nett $4.83 \%$. Kondisi ini sejalan dengan penelitian Kuswahariani (2019) yaitu faktor yang berpengaruh signifikan terhadap NPF yaitu FDR, Net Operating Margin (NOM) dan Return On Equity (ROE). Ketiga variabel tersebut memiliki pengaruh negatif terhadap NPF. Kenaikan nilai FDR, NOM dan ROE akan menyebabkan pembiayaan bermasalah menurun.

Tingginya rasio NPF akan mempengaruhi kinerja perbankan syariah baik secara finansial maupun nonfinansial. Secara finansial, kondisi tersebut antara lain akan menurunkan profitabilitas dan permodalan karena kewajiban BUS untuk membentuk biaya penurunan nilai pembiayaan yang lebih tinggi (Budiman, 2014). Dengan menurunnya kolektibilitas 2 ke kolektibilitas 3 dan 4, di tahun 2017 BUS terkena tambahan beban PPAP sehingga membukukan kerugian Rp 968.85 miliar yang berakibat pada penurunan modal bank. Hal ini menyebabkan induk perusahaan, Bank Panin, harus melakukan setoran modal sebesar Rp 421 miliar guna menjaga PDSB tetap berada dalam kategori BUKU 2. 
ROA turun sebagai dampak dari kerugian dan penurunan modal hingga menyentuh posisi minus yaitu $-10.71 \%$. Kecukupan modal yang digambarkan oleh CAR juga turun menjadi $11.71 \%$. Peningkatan NPF juga memiliki dampak nonfinansial yaitu mempengaruhi citra perbankan syariah yang kurang mampu mengelola pembiayaan dengan baik dan akan menurunkan tingkat kepercayaan baik dari nasabah penyimpan maupun masyarakat pada umumnya terhadap perbankan syariah (Budiman, 2014).

Selain upaya perbaikan secara internal perusahaan juga diperlukan upaya perbaikan secara sinergi antara perusahaan anak dengan perusahaan induk bank konvensional antara lain dengan memperbanyak penempatan outlet bank syariah pada kantor cabang induk (office channeling), diferensiasi produk perbankan syariah yang lebih unik, melakukan pengembangan strategi pemasaran bersama antara lain dengan joint product, cross selling atau sindikasi, dan meningkatkan efisiensi dengan melakukan sharing infrastruktur (Nurwati, 2014).

Di sisi pembiayaan, strategi reprofiling masih belum menunjukkan perubahan yang cukup berarti dan belum terdapat pertumbuhan pembiayaan karena PDSB masih fokus pada collection dan recovery. PDSB juga mulai melakukan pembatasan penyaluran pembiayaan ke segmen komersial dan korporasi. Kinerja bank terpengaruh hingga hampir seluruh indikator keuangan mengalami penurunan. Aset turun sebesar $1.47 \%$ menjadi Rp 8.63 triliun bertolak belakang dengan pertumbuhan aset BUS sebesar $13.31 \%$. BOPO meningkat menjadi $217.40 \%$ sebagai dampak dari proses konsolidasi dan transformasi yang terjadi.

Penurunan kinerja keuangan tahun 2017 diikuti dengan penurunan seluruh skor efisiensi. Berdasarkan TE, pembiayaan murabahah menjadi penyebab inefisiensi terbesar di tahun 2017 sehingga perlu dilakukan perbaikan dengan peningkatan sebesar $41.30 \%$. Berdasarkan PTE, perbaikan dilakukan pada dua variabel yaitu biaya tenaga kerja dan pembiayaan murabahah. Tingginya biaya tenaga kerja ditengah penurunan kinerja keuangan PDSB menjadi penyebab inefisiensi terbesar tahun 2017.

Walaupun terjadi penurunan, skor PTE dan TE PDSB sepanjang tahun 2010-2017 selalu lebih efisien bila dibandingkan dengan rata-rata BUS BUKU 2 maupun agregat BUS. Porsi kepemilikan saham publik di PDSB hanya berkisar 40\% sehingga kinerja keuangan yang dilaporkan pasca IPO yang tidak sepenuhnya dapat mengungkapkan kinerja perusahaan. Salah satunya adalah pelaksanaan IPO PDSB yang meningkatkan efisiensi secara signifikan setelah go public daripada yang tidak melakukan IPO, namun tidak menunjukkan efisiensi dalam jangka panjang.

Pada uji beda pra dan pasca IPO PDSB terdapat perbedaan signifikan hanya pada parameter CAR, dimana CAR pra IPO PDSB lebih baik dibandingkan CAR pasca IPO PDSB. Sedangkan efisiensi TE, PTE, SE, BOPO, NPF, dan FDR tidak ada perbedaan siginifikan antara rata-rata parameter pra IPO dan pasca IPO PDSB.

Pada uji beda BUS BUKU 2 dan PDSB kondisi pra IPO terdapat perbedaan signifikan pada efisiensi TE, efisiensi PTE, efisiensi SE, CAR, dan NPF. Efisiensi TE, PTE dan SE PDSB lebih efisien dari BUS BUKU 2. CAR PDSB lebih baik dari CAR BUS BUKU 2. NPF PDSB lebih baik dari NPF BUS BUKU 2.

Pada uji beda BUS BUKU 2 dan PDSB pasca IPO terdapat perbedaan yang signifikan pada efisiensi TE dan efisiensi SE. Efisiensi TE dan SE PDSB lebih efisien dari BUS BUKU 2. Hasil uji beda selanjutnya menunjukkan tidak terdapat perbedaan yang signifikan pada efisiensi PTE, ROA, BOPO, CAR, NPF, dan FDR. Terdapat perubahan CAR dan NPF yang semula berbeda signifikan pada pra IPO, kemudian menjadi tidak berbeda signifikan pada pasca IPO. 


\section{SIMPULAN DAN SARAN}

\section{Simpulan}

Kinerja keuangan PDSB pra IPO sangat baik bahkan hampir selalu di atas kinerja rata-rata BUS BUKU 2. Kinerja yang baik ini sebagai landasan PDSB melakukan IPO dan dapat menarik minat masyarakat untuk membeli saham PDSB. Kinerja keuangan PDSB yang baik hanya bertahan sampai tahun pelaksanaan IPO pada tahun 2014. Sejak tahun 2015, BUS BUKU 2 lainnya mulai menunjukkan perbaikan kinerja keuangan. Sebaliknya, PDSB mengalami kecenderungan penurunan kinerja keuangan. Kinerja keuangan PDSB tidak kunjung membaik di mana ROA, CAR, NPF dan BOPO tahun 2017 tercatat sebagai rasio terburuk dalam sejarah perbankan syariah di Indonesia. CAR pra IPO lebih baik dibandingkan pasca IPO. Sedangkan efisiensi TE, PTE, SE, BOPO, NPF, dan FDR tidak ada perbedaan siginifikan antara rata-rata parameter pra IPO dan pasca IPO.

Skor efisiensi PDSB sepanjang periode pengamatan tahun 2010-2017 selalu lebih efisien bila dibandingkan BUS BUKU 2. Pada kondisi pra IPO skor TE, skor PTE dan skor SE PDSB lebih efisien daripada BUS BUKU 2. Pada kondisi pasca IPO skor TE dan skor SE lebih efisien daripada BUS BUKU 2. Hasil penelitian ini konsisten dengan beberapa penelitian terdahulu mengenai efisiensi yaitu:

1. Bank syariah belum beroperasi secara efisien jika dilihat dari skor efisiensi yang besarnya kurang dari 100.

2. Tidak ada perbedaan signifikan skor efisiensi pada berbagai ukuran dan tingkat umur perusahaan.

3. Dari jenis kepemilikan, bank syariah milik pemerintah lebih efisien dibandingkan dengan bank syariah swasta.

4. Bank syariah mengalami kondisi tidak efisien secara teknis selama krisis finansial.

5. Efisiensi BUS BUKU 2 tidak berbeda dengan yang dialami oleh bank syariah di luar negeri sebagai dampak dari kondisi perekonomian global.

\section{Saran}

Pembahasan dalam penelitian ini diharapkan dapat bermanfaat bagi:

1. Manajemen PDSB

Manajemen PDSB dapat melakukan perbaikan efisiensi teknis (TE) dengan melakukan peningkatan pembiayaan murabahah. Perbaikan efisiensi teknis murni (PTE) dengan pengurangan biaya tenaga kerja dan peningkatan pembiayaan murabahah.

PDSB dapat menekan biaya tenaga kerja dengan tidak melakukan perekrutan tenaga kerja baru melainkan peningkatan kualitas SDM melalui pelatihan untuk membentuk SDM berkualitas sesuai tuntutan SDM dalam industri perbankan syariah. Selain product knowledge, SDM perbankan syariah diharapkan memiliki karakteristik jujur dan akuntabel sehingga dapat mencerminkan nilai-nilai luhur yang sesuai dengan maqasid syariah.

PDSB dapat meningkatkan pembiayaan murabahah yang merupakan katalis pembiayaan pada sektor ekonomi yang prospektif dan berkesinambungan. Peningkatan nilai pembiayaan murabahah segmen komersil telah sejalan dengan salah satu rencana bisnis PDSB yaitu reprofiling segmentasi pembiayaan, agar tercapai porsi segmentasi pembiayaan yang memadai antara segmen korporasi, komersil dan ritel.

2. Industri perbankan syariah di Indonesia, khususnya BUS yang akan dan telah melaksanakan IPO dapat mempertimbangkan hal-hal sebagai berikut:

a. Pelaksanaan IPO pada awalnya bertujuan untuk menguatkan kapasitas permodalan yang mampu meningkatkan kemampuan manajemen untuk mengelola BUS menjadi lebih efisien. Namun pasca pelaksanaan IPO, PDSB rasio keuangan perusahaan yang diwakili oleh ROE, CAR, NPF, FDR, dan BOPO tidak ada perbedaan dan tidak lebih unggul apabila dibandingkan dengan BUS. Status sebagai perusahaan go public mampu meningkatkan 
efisiensi, namun belum mampu meningkatkan kinerja keuangan perusahaan maupun harga saham secara berkelanjutan.

b. Langkah strategis dalam rangka perbaikan TE dengan pengurangan nilai pada variabel aset tetap dan biaya tenaga kerja. Perbaikan efisiensi juga dilakukan dengan peningkatan nilai variabel pembiayaan bagi hasil dan investment. Perbaikan PTE dapat ditempuh dengan pengurangan nilai aset tetap dan peningkatan nilai variabel investment dan pembiayaan bagi hasil.

3. Bagi akademisi, penelitian ini terbatas pada kinerja keuangan PDSB dan BUS BUKU 2 pra dan pasca IPO (tahun 2010-2017). Penelitian selanjutnya diharapkan menggunakan tahun pengamatan yang lebih panjang dan dalam skala industri yang lebih besar sehingga dapat dilakukan penelitian yang lebih mendalam. Penelitian ini terbatas menggunakan metode DEA untuk mengukur skor efisiensi. Penelitian selanjutnya diharapkan menggunakan metode yang berbeda sehingga dapat dijelaskan lebih lanjut mengenai penyebab memburuknya kinerja PDSB pasca IPO.

4. Bagi regulator perlu melakukan kajian mendalam mengenai penguatan modal bank syariah melalui IPO. Regulator agar melakukan pengawasan intensif bagi BUS yang akan dan telah melakukan IPO untuk meminimalisi terjadinya penurunan kinerja keuangan yang dapat mempengaruhi pertumbuhan industri perbankan syariah.

\section{DAFTAR PUSTAKA}

Abraham, R., Harris, J., \& Auerbach, J. (2016). IPO performance at announcement and in the aftermarket. Journal of Economic Studies, 43(4), 574-586.

Ascarya \& Yumanita, D. (2006). Analisis efisiensi perbankan syariah di Indonesia dengan Data Envelopment Analysis. TAZKIA Islamic Finance and Business Review, 1(2), 1-32.

Banker, R.D., Charnes, A. \& Cooper, W.W. (1984). Some models for estimating technical and scale inefficiency in Data Envelopment Analysis. Management Science, 30(9), 1078-1092.

Berger, A.N., \& Humphrey, D.B. (1997). Efficiency of financial institutions: international survey and directions for future research. European Journal of Operational Research, 98(2), 175-212.

Budiman, R. (2014). Analisis risiko pembiayaan dan determinannya pada perbankan syariah di Indonesia. [tesis]. Bogor, Institut Pertanian Bogor.

Charnes, A., Cooper, W.W. \& Rhodes, E. (1978). Measuring efficiency of decision making units. European Journal of Operations Research, 2, 429-444.

Fatmala, E. (2018). Analisis efisiensi perbankan sebelum dan setelah krisis keuangan tahun 2008. [tesis]. Bogor, Institut Pertanian Bogor.

Hadad, M.D., Sugiarto, A., Purwanti, W., Hermanto, M.J., \& Arianto, B. (2003). Kajian mengenai struktur kepemilikan bank di Indonesia. Jurnal Buletin Ekonomi dan Moneter Bank Indonesia, Jakarta.

Hendy, M.F. (2008). Go Public: Strategi Pendanaan dan Peningkatan Nilai Perusahaan. Jakarta (ID), PT Alex Media Komputindo.

Karimah, S. (2016). Kajian efisiensi bank umum syariah di Indonesia dan faktor-faktor yang memengaruhinya. [tesis]. Bogor, Institut Pertanian Bogor.

Kuswahariani, W. (2019). Analisis non performing financing pada tiga bank syariah nasional segmen mikro dan secara umum. [tesis]. Bogor, Institut Pertanian Bogor.

Kwan, S.H. (2003). Operating performance of banks among Asian economies: an international and time series comparison. Journal of Banking \& Finance, 27(3), 471-489.

Majeed, M.T. \& Zanib, A. (2016). Efficiency analysis of Islamic banks in Pakistan. Humanomics, 32(1), 19-32.

Mansyur, F. (2012). Analisis perbandingan efisiensi bank umum syariah dan bank umum konvensional di Indonesia menggunakan metode Stochastic Frontier Approach (SFA). [tesis]. Yogyakarta, UIN Sunan Kalijaga Yogyakarta. 
Mezzi, N. (2018). Efficiency of Islamic banks and role of governance: empirical evidence. Managerial Finance, 44(5), 590-603.

Hassan, T., Mohamad, S. \& Bader, M.K.I. (2009). Efficiency of conventional versus Islamic banks: evidence from the middle east, International Journal of Islamic and Middel Eastern Finance and Management, 2(1).

Nurwati, E. (2014). Kinerja bank umum syariah, dan keterkaitannya dengan perusahaan induk bank konvensional. [disertasi]. Bogor, Institut Pertanian Bogor.

Puteh, A., Rasyidin, M. \& Mawaddah, N. (2017). Islamic banks in Indonesia: Analysis of efficiency. Emerald Reach Proceedings Series, 1, 331-336.

Qureshi, M.A. \& Shaikh, M. (2012). Efficiency of Islamic and conventional banks in Pakistan: a nonparametric approach. International Journal of Business and Management, 7(7), 40-50.

Said, A. (2013). Evaluating the overall technical efficiency of Islamic banks operating in the MENA region during the financial crisis. International Journal of Economics and Financial Issues, 3(2), 426-434.

Sharma, D., Sharma, A.K. \& Barua, M.K. (2013). Efficiency and productivity of banking sector: a critical analysis of literature and design of conceptual model. Qualitative Research in Financial Markets, 5(2), 195-224.

Wheelock, D.C. \& Wilson, P.W. (1999). Technical progress, inefficiency, and productivity change in US banking, 1984-1983. Journal of Money, Credit and Banking, 31(2), 212-34.

Yahya, M.H., Muhammad, J. \& Hadi, A.R.A. (2012). A comparative study on the level of efficiency between Islamic and conventional banking systems in Malaysia. International Journal of Islamic and Middle Eastern Finance and Management, 5(1), 48-62.

Yin, H., Yang, J. \& Mehran, J. (2015). Do Chinese banks perform better after IPOs? Managerial Finance, 41(4), 368-384.

Zeineb, G.B. \& Mensi, S. (2018). Corporate governance, risk and efficiency: Evidence from GCC Islamic banks. Managerial Finance, 44(5), 551-569. 